\title{
Thermophysiological vulnerability to Heat stress among Indoor workers
}

\author{
Dutta P. ${ }^{1 *}$, Chorsiya V. ${ }^{2}$ \\ DOI: https://doi.org/10.17511/ijphr.2014.i1.04
}

1* Priya Dutta, Research Associate, Indian Institute of Public Health, Ahmedabad, Gujrat, India.

2 Varsha Chorsiya, Manav Rachana international university, Faridabad, Haryana, India.

Introduction: The present study provides a practical importance to assess the magnitude of thermal stress of workers in indoor environment taking into account the workers physiological responses. Method: The study covered indoor workers iron ( $N=587$ years) and ceramics $(N=426)$ in three seasons. Thermal measurements were recorded by Wet Bulb Globe Temperature (WBGT) Monitor. The physiological responses include skin temperature, heart rate and blood pressure. Results: The WBGT index in summer month of ceramic $\left(34.9 \pm 2.7^{\circ} \mathrm{C}\right)$ was higher than iron foundry works $\left(32 \pm 1.7^{\circ} \mathrm{C}\right)$. The systolic blood pressures in winter month were higher, as compared to summer months $(2 \mathrm{mmHg}$ in iron and $11 \mathrm{mmHg}$ in ceramic). About $32 \%$ of iron and ceramic workers had working heart rate greater than 100 beats/min and $3 \%$ beyond 130 beats/min during the working day. The skin temperature (Tsk) profile and weighted skin temperature (Tsk) were significantly higher in summer, followed by post-monsoon and winter months. Discussion: The study assesses the physiological and thermoregulatory responses of workers to heat stress and strain for their exposure to extreme hot environment. The limit of peripheral thermoregulatory adjustability may be considered beneficial and can be taken away from the fury of high heat.

Keywords: Thermal stress, WBGT, Tolerance time, Physiological response

Corresponding Author

Priya Dutta, Research Associate, Indian Institute of Public Health, Ahmedabad, Gujrat, India.

Email: priyadutta@iiphg.org
How to Cite this Article

Dutta P, Chorsiya V. Thermophysiological vulnerability to Heat stress among Indoor workers. Public Health Rev Int J Public Health Res. 2014;1(1):18-24.

Available From

https://publichealth.medresearch.in/index.php/ijphr/ article/view/4
To Browse

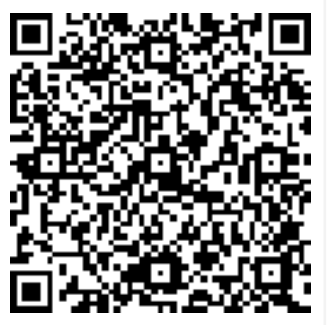

Manuscript Received 2014-04-11

Conflict of Interest No
Review Round 1 2014-04-15

Funding

Nil

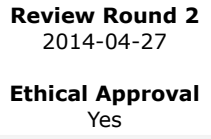

Review Round 3

Plagiarism X-checker $5 \%$
Accepted 2014-05-12

Note

(c) 2014 by Priya Dutta, Varsha Chorsiya and Published by Siddharth Health Research and Social Welfare Society. This is an Open Access article licensed under a Creative Commons Attribution 4.0 International License https://creativecommons.org/licenses/by/4.0/ unported [CC BY 4.0]. 


\section{Introduction}

Human health and the environment are closely associated. The western part of India (Gujarat) is highly prone to heat waves at regular frequency. In Gujarat the average summer month temperature ranges from $27^{\circ} \mathrm{C}$ to $42^{\circ} \mathrm{C}$ and have been known to reach as high as $48^{\circ} \mathrm{C}$. During the winter month average temperature ranges from $15^{\circ} \mathrm{Cto} 28^{\circ} \mathrm{C}$.

The increase in surface temperature and industrial activity are leading to higher temperatures res which resulted in the potential risk of high heat exposure to workers. The summer of 2010 records the hottest summer in many areas of Gujarat, with temperatures approximately $48^{\circ} \mathrm{C}$. The effects include hospitalization because of heat stroke, suffering of livestock, and severe drought in some regions that affected health as well as agriculture.

Besides naturally occurring hot climate in these geographical regions, artificial exposure situations such as working in workplaces near the boilers, furnaces, heat treatment tanks, steam pipes, foundries, glass manufacturing, ceramic tile work, molten metal operations etc. often exceed the climatic stresses as a consequence of the cumulative effect on the health of the workers. For example, working in the ceramic tile or metal foundry industry around furnaces or kilns is extremely hot. Significant heat stress problems can occur during routine work in firing or melting processes.

Severe thermal burns or heat disorders can result from direct skin contact with hot surfaces or molten materials. Such heat stress causes health risks and manifest in decrease in work productivity, with a consequent negative impact on family income and the community economy [1]. Thus protecting workers against heat illness is important from both moral and economic perspectives. Epidemiological and experimental researches elucidate the challenges of thermoregulation among people in an extreme hot environment [2]. Dash and Kjellstrom [3] reported that in western India during summer season there is relatively more increase in the daily maximum temperature followed by Bihar, Uttar Pradesh and Orissa.

Management of heat exposure is important to safeguard human health in the industry and community environment. Heat stress is a potential health hazard for workers who are exposed to high environmental heat for prolonged periods.
Studies have examined the length of tolerance time in which humans can tolerate high temperatures, either when they are at rest or working $[4,5]$.

A substantial amount of body water may be lost as sweat, including loss of fluid through respiration, gastrointestinal tract as well as kidney [6] which disturbs the homeostasis of the body, leading to decreased skin blood flow, elevated core body temperature (Tcr), decreased sweating rate, tolerance to work and increased risks of heat injuries $[7,8]$. Studies suggested that self-pace of work can regulate ones workload under thermally stressful conditions to avoid physiological strain [9].

There is lack of Indian heat exposure guideline for determining ceiling limits of environmental exposure for tropical heat exposure of the population. More of, in India, research studies highlighting physiological and thermal stress among indoor occupational groups are subdued. The present research program focussed on a heat-health vulnerability assessment in indoor occupational groups i.e., Iron foundry and ceramic work.

\section{Method and materials}

A crosssectional survey was conducted in Gujarat (2010-2012).In order to find the seasonal variation the survey was conducted in three broad seasons i.e. summer (May and June), post monsoon (September and October) and winter (December and January). A total of 1013 subjects was surveyed which includes iron foundry work in Ahmedabad $(\mathrm{N}=587)$ and Ceramic work in Morvi \& Than $(\mathrm{N}=426)$.

Iron foundry work includes casting molten metal in a mold, cooling the cast, fettling, cutting of iron sheets, bending, drilling, punching, welding, riveting and finishing. The molten metal is poured into mold traditionally by hand using ladles. Ceramic work includes crushing, grinding and casting of the raw material, coloring/ spraying, hardening by heat, sorting and cooling.

The workers in these occupations are potentially exposed to high source of heat, fumes and noise, in addition to strenuous physical activity (Figure 1). During work, the workers usually wear light clothing like shorts, and a half-sleeve banian or t-shirt with insulation values ranged within 0.6 clo.

The survey was conducted during the working period between $11 \mathrm{am}$ to $4 \mathrm{pm}$ in all seasons. 
The workers more than 18 years of age participated in the study and the informed consent was taken as per the Indian Council of Medical Research (2000) ethical guidelines [10]. The environmental measurements includes ambient dry bulb ( $\mathrm{Ta})$, dew point, wetbulb (Twb), globe temperature $(\mathrm{Tg})$, wind velocity, Relative humidity and WBGT index measured by WBGT Monitor, Delta OHM (HD 32.1

Thermal Microclimate, Italy) and Lascar data logger (Lascar EL-USB-2-LCD, Sweden) for several hours ofobservation period and continued for a number of days at each workplace. The environmental warmth was expressed in terms of WBGT index $[11,12]$. Thephysiological heat strain parameters include sweating response, heart rate and blood pressure measurements. Sweating response is the net change in body weight after a given period of exposure [13].

The digital BP instrument was used to record the blood pressure during the work $[14,15]$. Heart rate was measured by polar heart rate meter (S810TM Polar Electro Oy, Finland) [16]. Due to safety and convenience in measurement of large number of workers in field situations, the oral temperature was taken as the Tcr.

The infrared thermographic camera (ThermoCAM, FLIR system, Sweden) was used for body temperature profiling of the local skin areas (Tsk) forentiresample population. The weighted average Tsk was obtained from the segmental surface area and sensitivity weighting of local skin areas [17], as below:

Weighted TSk $=0.095$ Head Tsk +0.255 Trunk Tsk $+0.245 \mathrm{Ba}+0.205$ Thigh Tsk + 0.04 Foot Tsk

All data were analyzed using SPSS16.0 software. The statistical analysis used in the present work includesdescriptivestatistics, analysis of variance (ANOVA) and Tukey's HSD post-hoc test.

\section{Result}

The physical characteristics of the workers are given inTable1. On average, the workers had similar anthropometric dimensions. The Ceramic workers were relatively younger $(25.5 \pm 7.4$ year)thaniron foundry worker (31.9 11.0 year).

Table 1: Physical characters of workers

\begin{tabular}{|l|l|l|}
\hline & Iron Foundry work $(\mathrm{N}=\mathbf{5 8 7})$ & Ceramic work $(\mathrm{N}=\mathbf{4 2 6})$ \\
\hline Age (years) & $31.9 \pm 11.0$ & $25.5 \pm 7.4$ \\
\hline
\end{tabular}

\begin{tabular}{|l|l|l|}
\hline Body weight $(\mathrm{kg})$ & $55.7 \pm 11.1$ & $51.3 \pm 7.5$ \\
\hline Body height $(\mathrm{cm})$ & $161.9 \pm 8.6$ & $162.5 \pm 8.5$ \\
\hline Body surface area $(\mathrm{sqm})$ & $1.6 \pm 0.2$ & $1.5 \pm 0.1$ \\
\hline BMI $(\mathrm{kg} / \mathrm{m} 2)$ & $21.1 \pm 3.9$ & $19.5 \pm 2.9$ \\
\hline
\end{tabular}

The average recorded climatic conditions during three different seasons are presented in Table 2 . The wet bulb temperature (Twb) for the summer month narrowly varies among iron and ceramic occupational groups, i.e., $29.3 \pm 4.1^{\circ} \mathrm{C}$ and $34.6 \pm 5.8^{\circ} \mathrm{C}$ respectively. Day time ambient dry bulb temperature $(\mathrm{Ta})$ of the workplace ranged from 30 to $44^{\circ} \mathrm{C}$ in iron foundry works and 25 to $45^{\circ} \mathrm{C}$ in ceramic works. The WBGT index in the summer month of ceramic $\left(34.9 \pm 2.7^{\circ} \mathrm{C}\right)$ was higher than iron foundry works $\left(32 \pm 1.7^{\circ} \mathrm{C}\right)$. About $94 \%$ of workers of iron foundry work and $70 \%$ of ceramic work were exposed at the environmental warmth in the mean range from 30.1 to $35.5^{\circ} \mathrm{C}$ WBGT respectively. Also in winter, the environmental warmth of the iron foundry work workers was high due to the work processes generating localized heat. The WBGT values vary distinctively by occupational activity and seasons among indoor occupational groups. One-way ANOVA yielded significant seasonal differences in environmental warmth $(p<0.001)$ in different occupational groups. However, post hoc multiple comparisons using Tukey's test did not showed a significant differences between summer and post monsoon month. The working climate is the indication of the occupational groups being exposed to high heat and is at potential risk of heat related illnesses.

\section{Table 2: Environmental conditions recorded at} workplaces

\begin{tabular}{|c|c|c|c|c|}
\hline & $\begin{array}{l}\text { Summer } \\
\text { (May - } \\
\text { June) }\end{array}$ & $\begin{array}{l}\text { Post-monsoon } \\
\text { (September- } \\
\text { October) }\end{array}$ & $\begin{array}{c}\text { Winter } \\
\text { (December- } \\
\text { January) }\end{array}$ & F values \\
\hline \multicolumn{5}{|c|}{ Iron foundry work, $(\mathrm{N}=587)$} \\
\hline $\mathrm{Ta}\left({ }^{\circ} \mathrm{C}\right)$ & $39.1 \pm 1.7$ & $33.8 \pm 3.9$ & $36.6 \pm 3.8$ & $127.3(p<0.001)$ \\
\hline $\operatorname{Twb}\left({ }^{\circ} \mathrm{C}\right)$ & $29.3 \pm 4.1$ & $35.7 \pm 4.5$ & $38.7 \pm 4.0$ & $319.9(p<0.001)$ \\
\hline $\operatorname{Tg}\left({ }^{\circ} \mathrm{C}\right)$ & $40 \pm 5.0$ & $33.2 \pm 3.3$ & $27.7 \pm 4.6$ & $419.1(p<0.001)$ \\
\hline WBGT $\left({ }^{\circ} \mathrm{C}\right)$ & $32 \pm 1.7$ & $33.3 \pm 2.7$ & $31.1 \pm 2.8$ & $31.2(p<0.001)$ \\
\hline \multicolumn{5}{|c|}{ Ceramic work, $(\mathrm{N}=426)$} \\
\hline $\mathrm{Ta}\left({ }^{\circ} \mathrm{C}\right)$ & $39.3 \pm 3.6$ & $36.2 \pm 3.1$ & $26.9 \pm 1.2$ & $394.6(p<0.001)$ \\
\hline Twb $\left({ }^{\circ} \mathrm{C}\right)$ & $34.6 \pm 5.8$ & $38.3 \pm 3.7$ & $31.8 \pm 1.0$ & $56.1(p<0.001)$ \\
\hline $\operatorname{Tg}\left({ }^{\circ} \mathrm{C}\right)$ & $39.1 \pm 5.0$ & $34.1 \pm 3.9$ & $24.2 \pm 0.7$ & $325.5(p<0.001)$ \\
\hline $\begin{array}{l}\text { WBGT } \\
\left({ }^{\circ} \mathrm{C}\right)\end{array}$ & $34.9 \pm 2.7$ & $34.8 \pm 2.1$ & $26.5 \pm 0.8$ & $392.3(p<0.001)$ \\
\hline
\end{tabular}

The magnitudes of physiological strains due to the environmental warmth (different seasons of work) were shownin Table 3. 
Data indicated that the combined stress of work and heat imposed significant physical load on the workers, with potential health consequences. About $32 \%$ of iron foundry and ceramic workers, had working heart rate greater than 100 beats $/ \mathrm{min}$. Whereas, $3 \%$ of iron foundry and ceramic workers had heart rates beyond 130 beats/min during the working day.

The systolic blood pressures of iron foundry and ceramic workers varied closely in different seasons, while the observations during the month of winter were marginally higher, as compared to the summer months (i.e., $2 \mathrm{~mm} \mathrm{Hg}$ in case of iron foundry work and $11 \mathrm{~mm} \mathrm{Hg}$ in ceramic work). Also there was no difference in diastolic blood pressure among the occupational groups during three seasons [18].

The sweat loss of the workers in iron foundry and ceramic during summer were $12.6 \pm 1.3$ and $14.8 \pm 2.0 \mathrm{gm} / \mathrm{min}$ respectively (i.e., 3 to 3.7 litre ofsweating for 4 hours of exposure). During summer, the heat stress index (HSI) of iron foundry workers was comparatively higher $(114 \pm 46)$, than ceramic work $(100 \pm 36)$. Exceeding of HSI values above100 indicating considerable body heating and physiological strain.

\section{Table-3: Physiological responses of the workers}

\begin{tabular}{|c|c|c|c|c|}
\hline & $\begin{array}{c}\text { Summer } \\
\text { (May- } \\
\text { June) }\end{array}$ & $\begin{array}{c}\text { Post-monsoon } \\
\text { (September- } \\
\text { October) }\end{array}$ & \begin{tabular}{|c|} 
Winter \\
(December- \\
January)
\end{tabular} & F values \\
\hline \multicolumn{5}{|c|}{ Iron Foundry work, $(\mathrm{N}=587)$} \\
\hline & $(N=287)$ & $(N=104)$ & $(N=196)$ & \\
\hline \begin{tabular}{|l|} 
Heart Rate \\
(beats $/ \mathrm{mi}$ \\
n)
\end{tabular} & $97 \pm 12$ & $103 \pm 24$ & $98 \pm 18$ & $22.2(p<0.001)$ \\
\hline \begin{tabular}{|l|} 
Tolerance \\
Time \\
$(\mathrm{min})$
\end{tabular} & $93.8 \pm 14.3$ & $84.4 \pm 17.4$ & $104.4 \pm 27.3$ & $36.1(p<0.001)$ \\
\hline $\begin{array}{l}\text { Sweat loss } \\
(\mathrm{gm} / \mathrm{min})\end{array}$ & $12.6 \pm 1.3$ & $13.6 \pm 2.1$ & $11.9 \pm 2.2$ & $31.2(p<0.001)$ \\
\hline \begin{tabular}{|l} 
Systolic \\
BP (mm \\
$\mathrm{Hg})$
\end{tabular} & $132 \pm 15.2$ & $131 \pm 15.0$ & $134 \pm 16.4$ & 2.2 (NS) \\
\hline $\begin{array}{l}\text { Diastolic } \\
\mathrm{BP}(\mathrm{mm} \\
\mathrm{Hg})\end{array}$ & $86 \pm 37.9$ & $80 \pm 11.8$ & $79 \pm 11.9$ & $4.7(p<0.05)$ \\
\hline HSI & $\begin{array}{l}114.2 \pm 45 . \\
5\end{array}$ & $83.9 \pm 36.3$ & $108.9 \pm 49.6$ & $13.3(p<0.001)$ \\
\hline \multicolumn{5}{|c|}{ Ceramic work, $(\mathrm{N}=426)$} \\
\hline . & $(N=193)$ & $(N=166)$ & $(\mathrm{N}=67)$ & \\
\hline
\end{tabular}

\begin{tabular}{|l|l|l|l|l|}
\hline $\begin{array}{l}\text { Heart Rate } \\
\text { (beats/min) }\end{array}$ & $103 \pm 15$ & $97 \pm 15$ & $97 \pm 15$ & $0.04(\mathrm{NS})$ \\
\hline Tolerance Time $(\mathrm{min})$ & $73.1 \pm 17.3$ & $72.9 \pm 14$. & $155.4 \pm 11$. & $809.8(\mathrm{p}<0.001)$ \\
\hline Sweat loss $(\mathrm{gm} / \mathrm{min})$ & $14.8 \pm 2.0$ & $14.7 \pm 1.6$ & $8.3 \pm 0.6$ & $392.3(\mathrm{p}<0.001)$ \\
\hline Systolic BP $(\mathrm{mm} \mathrm{Hg})$ & $129 \pm 18.7$ & $132 \pm 12.6$ & $140 \pm 12.8$ & $12.6(\mathrm{p}<0.001)$ \\
\hline Diastolic BP $(\mathrm{mm} \mathrm{Hg})$ & $80 \pm 11.6$ & $81 \pm 13.2$ & $77 \pm 9.2$ & $2.2(\mathrm{NS})$ \\
\hline HSI & $100.1 \pm 35$. & $79.9 \pm 35$. & $93.8 \pm 47.3$ & $10.7(p<0.001)$ \\
\hline & 8 & 5 & & \\
\hline \multicolumn{5}{|l|}{ Values are means \pm SD. } \\
\hline
\end{tabular}

The relative influence on Tsk requires to be evaluated in order to better understand the dynamics of human thermoregulatory mechanism. The Tsk profile of the human body is often taken as the first rank strain indicator in extremely hot situations.

Figure 1 shows an infrared profile of a different body area of a workerin iron foundry industry. The Tsk tends to increase with the rise in thermal stress, as one of the effective thermoregulatory effort of the human body. The magnitudes of local Tsk
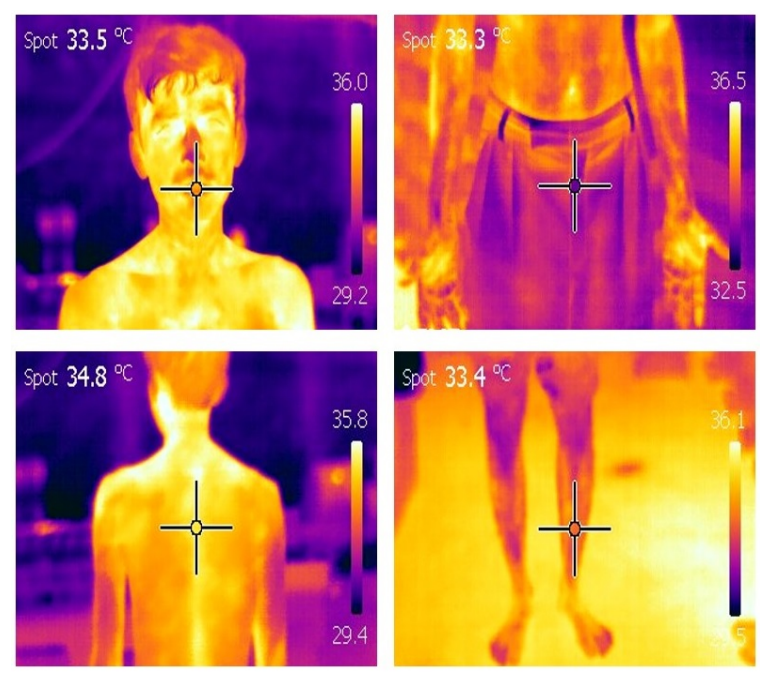

\section{Fig-1: Sample Infrared thermography profile of different body areas of a worker}

Varied significantly in different working seasons ( $T$ able 4) and accordingly, the weighted Tsk also varied with values being higher in summer, followed by post-monsoon and winter months. However there was a narrow difference in local and weighted Tsk between the working groups.

Table 4: Local skin temperature (Tsk) profile of workers at workplace 


\begin{tabular}{|c|c|c|c|c|}
\hline & $\begin{array}{l}\text { Summer } \\
\text { (May- } \\
\text { June) }\end{array}$ & $\begin{array}{l}\text { Post-monsoon } \\
\text { (September- } \\
\text { October) }\end{array}$ & $\begin{array}{l}\text { Winter } \\
\text { (December- } \\
\text { January) }\end{array}$ & $F$ values \\
\hline \multicolumn{5}{|c|}{ Iron Foundry work, $(\mathrm{N}=587)\left(\right.$ in $\left.{ }^{\circ} \mathrm{C}\right)$} \\
\hline & $(N=287)$ & $(N=104)$ & $(N=196)$ & \\
\hline $\begin{array}{l}\text { Tsk } \\
\text { (Head) }\end{array}$ & $35.4 \pm 0.7$ & $35.3 \pm 1.0$ & $35.3 \pm 1.2$ & $\begin{array}{l}4.3 \\
(p<0.05)\end{array}$ \\
\hline $\begin{array}{l}\text { Tsk } \\
\text { (Back) }\end{array}$ & $35.6 \pm 1.1$ & $35.1 \pm 0.8$ & $34.5 \pm 1.1$ & $\begin{array}{l}59.5 \\
(p<0.001)\end{array}$ \\
\hline $\begin{array}{l}\text { Tsk } \\
\text { (Trunk) }\end{array}$ & $35.6 \pm 0.9$ & $34.7 \pm 0.9$ & $33.8 \pm 1.2$ & $\begin{array}{l}157.5 \\
(p<0.001)\end{array}$ \\
\hline $\begin{array}{l}\text { Tsk } \\
\text { (Upper } \\
\text { arm) }\end{array}$ & $36.1 \pm 1.0$ & $34.9 \pm 1.0$ & $33.6 \pm 1.4$ & $\begin{array}{l}246.3 \\
(p<0.001)\end{array}$ \\
\hline $\begin{array}{l}\text { Tsk } \\
\text { (Hand) }\end{array}$ & $35.7 \pm 0.7$ & $34.4 \pm 0.9$ & $34.8 \pm 1.1$ & $\begin{array}{l}84.8 \\
(p<0.001)\end{array}$ \\
\hline $\begin{array}{l}\text { Tsk } \\
\text { (Thigh) }\end{array}$ & $36.4 \pm 0.9$ & $34.2 \pm 1.0$ & $33.5 \pm 1.2$ & $\begin{array}{l}429.3 \\
(p<0.001)\end{array}$ \\
\hline $\begin{array}{l}\text { Tsk } \\
\text { (Foot) }\end{array}$ & $36.4 \pm 1.1$ & $34.2 \pm 1.3$ & $33.3 \pm 1.5$ & $\begin{array}{l}314.9 \\
(p<0.001)\end{array}$ \\
\hline $\begin{array}{l}\text { Weighte } \\
\text { d Tsk }\end{array}$ & $35.8 \pm 0.8$ & $34.8 \pm 0.7$ & $34.0 \pm 1.0$ & $\begin{array}{l}223.1 \\
(p<0.001)\end{array}$ \\
\hline \multicolumn{5}{|c|}{ Ceramic work, $(\mathrm{N}=426)\left(\right.$ in $\left.{ }^{\circ} \mathrm{C}\right)$} \\
\hline & $(N=193)$ & $(N=166)$ & $(\mathrm{N}=67)$ & \\
\hline $\begin{array}{l}\text { Tsk } \\
\text { (Head) }\end{array}$ & $36.0 \pm 1.3$ & $35.8 \pm 1.4$ & $32.2 \pm 1.8$ & $\begin{array}{l}174.4 \\
(p<0.001)\end{array}$ \\
\hline $\begin{array}{l}\text { Tsk } \\
\text { (Back) }\end{array}$ & $35.6 \pm 1.1$ & $35.4 \pm 1.1$ & $34.1 \pm 1.2$ & $\begin{array}{l}46.2 \\
(p<0.001)\end{array}$ \\
\hline $\begin{array}{l}\text { Tsk } \\
\text { (Trunk) }\end{array}$ & $35.4 \pm 1.2$ & $34.9 \pm 1.1$ & $32.6 \pm 1.5$ & $\begin{array}{l}128.9 \\
(p<0.001)\end{array}$ \\
\hline $\begin{array}{l}\text { Tsk } \\
\text { (Upper } \\
\text { arm) }\end{array}$ & $35.6 \pm 1.5$ & $34.9 \pm 1.3$ & $27.8 \pm 3.1$ & $\begin{array}{l}474.8 \\
(p<0.001)\end{array}$ \\
\hline $\begin{array}{l}\text { Tsk } \\
\text { (Hand) }\end{array}$ & $35.5 \pm 1.1$ & $35.2 \pm 1.1$ & $32.8 \pm 1.6$ & $\begin{array}{l}130.4 \\
(p<0.001)\end{array}$ \\
\hline $\begin{array}{l}\text { Tsk } \\
\text { (Thigh) }\end{array}$ & $35.7 \pm 1.4$ & $34.6 \pm 1.1$ & $30.9 \pm 1.4$ & $\begin{array}{l}332.2 \\
(p<0.001)\end{array}$ \\
\hline $\begin{array}{l}\text { Tsk } \\
\text { (Foot) }\end{array}$ & $35.5 \pm 1.8$ & $34.8 \pm 1.2$ & $28.5 \pm 2.4$ & $\begin{array}{l}424.2 \\
(p<0.001)\end{array}$ \\
\hline $\begin{array}{l}\text { Weighte } \\
\text { d Tsk }\end{array}$ & $35.6 \pm 1.0$ & $35.1 \pm 1.0$ & $31.8 \pm 1.3$ & $\begin{array}{l}339.8 \\
(p<0.001)\end{array}$ \\
\hline
\end{tabular}

\section{Discussion}

The environmental conditions among indoor occupational groups with respect to different working seasons determine its influence on physiological responses, with reference to limit of heat tolerance. It was noted that even the habitual workers were at potential risks of developing heatrelated illness in the summer and post monsoon month exposures.
With reference to the level of $28^{\circ} \mathrm{C}$ WBGT as the suggested permissible exposures for acclimatized men in tropical heat [19], it was noted that high ambient heat load prevailed in all occupational groups during summer and post-monsoon. The ceramic workers had higher heat stress, as compared to iron work and the stress levels of the indoor workers were similar during summer and post-monsoon months.

The heart rate responses were higher during the summer months, followed by in the winter months. The data indicated a large range of seasonal variations, suggesting that the workers might be adopting self adjustment strategy in the pace of work. In the summer, there might be demands for channeling greater blood volume to the peripheral circulation for thermoregulatory (cooling) purposes, and in winter, there be increased metabolic requirement [20].

The present study observed a small increase in systolic blood pressure between different groups of workers during the winter months. The trend of the results corroborates to the findings of Krist al-Boneh et al. [20] that the average Systolic BP at work was higher in winter than in summer.

Alpe'rovitchetal [18] established the relationship between blood pressure and ambient temperature, showing that systolic blood pressure decreases with increasing temperature, i.e., $8 \mathrm{~mm} \mathrm{Hg}$ decrease between the lowest $\left(<7.9^{\circ} \mathrm{C}\right)$ and the highest $\left(>21.2^{\circ} \mathrm{C}\right)$ temperature. The mechanism that could explain the association between blood pressure and ambient temperature remains undetermined.

Activation of the sympathetic nervous system and secretion of catecholamine might be increased in a cooler environment, resulting in an increase in blood pressure through an increased heart rate and peripheral vascular resistance [18]. Hata et al. [21] attributed the increase in winter blood pressure to increased sympathetic nervous activity in cold weather.

In the present study, the seasonal changes showed no significant influence on diastolic BP in occupational activities, which is in accord with the results of Kim et al. [22] who observed the effects of heat stress on body temperature and blood pressure of elderly individuals.

In hot environments especially during work, the main role of thermoregulative mechanism is to dissipate excessive heat from the body. 
The most effective way of heat dissipation is sweat production and its evaporation from skin surface that results in loss of water and electrolyte $[23,24]$. Increase in sweat output often exceeds water intake which results in body water deficit (dehydration) or fatigue of sweat gland. Consequent, performance may be impaired and workers may pose a threat to health. The conditions of water requirement of informal workers are very much excruciating. It is critically important for the public system to develop a consistent approach to make able essential requirements for the workers where they live and work.

The study provided an understanding of the peripheral thermoregulatory adjustability that limits the ability of a worker to withstand heat exposure in indoor work environment. It was evident from the present study that towards body's thermoregulatory efforts, the local Tsk responses showed an increasing trend with the increasing thermal stress. In order to bring in proactive response in the event of extreme heat, therefore, the limit of peripheral thermoregulatory adjustability may be considered beneficial to devise actionable public health interventions, in order that the vulnerable groups can be taken away from the fury of high heat.

The above study bears considerable practical importance to assess the magnitude of worker's thermal stress and physiological reaction to ensure optimal conditions for health and productivity. The comprehensive analysis of the physiological and thermoregulatory responses of workers to heat stress and strain would eventually ascertain the relative vulnerability of the occupational groups for their exposure to extreme hot environment.

\section{Conclusion}

The climatic load and the metabolic heat load due to the severity of work to which a person is engaged together exert stress on the thermoregulatory system. The study provided an understanding that the limit of peripheral thermoregulatory adjustability which may be considered beneficial to devise actionable public health interventions, in order that the vulnerable groups canbe taken away from the fury of high heat. Often the discomforts attributed to environmental heat remains neglectedand unrecognized, and therefore, the perception of heat stress and associated illnesses carry substantial value.

\section{Reference}

01. Kjellstrom T, Holmer I, Lemke B. Workplace heat stress, health and productivity-an increasing ch allenge for low and middle-income countries dur ing climate change. Glob Heal Act. 2009;2.

[Crossref]

02. Bates GP, Miller VS. Sweat rate and sodium loss during work in the heat. J Occup Med Toxicol. 2008;3(4).

[Crossref]

03. Dash S, Kjellstrom T. Workplace heat stress in the context of rising temperature in India. Current Science. 2011;101(4)496. [Crossref]

04. Davies C. Thermal limits to severe prolonged exercise in man. Journal of Thermal Biology. 1993;18(5)605-607.

[Crossref]

05. Ignjatović A, Hofmann P, Radovanović D. Noninvasive determination of the anaerobic threshold based on the heart rate deflection point. Facta universitatis series Physical Education and Sport. 2008;6(1)1-10. [Crossref]

06. Parsons K. Maintaining health, comfort and prod uctivity in heat waves. Glob Heal Act. 2009;2. [Crossref]

07. Cheuvront SN, Carter R, Sawka MN. Fluid balance and endurance exercise performance. Curr Sports Med Rep. 2003;2(4)202-208. [Crossref]

08. Nag P, Dutta P, Nag A. Critical body temperature profile as indicator of heat stress vulnerability. Industrial health. 2012;51(1)113-122. [Crossref]

09. Miller VS, Bates GP. Hydration, hydration, hydration. Annals of occupational hygiene. 2010;54(2)134-136. [Crossref]

10. ICMR. Ethical guidelines for biomedical research on human subject. In Coun Medi Res. 2000. [Crossref]

11. Liljegren JC, Carhart RA, Lawday P, Tschopp S, Sharp R. Modeling the wet bulb globe temperature using standard meteorological measurements. Journal of Occupational and Environmental Hygiene. 2008;5(10)645-655. [Crossref] 
12. ACGIH. TLVs and BEIs-Threshold limit values for chemical substances and physical agents biological exposure indices. ACGIH Worldwide ISBN. 2002;1-882417.

[Crossref]

13. Nag PK, Nag A, Ashtekar SP. Thermal limits of men in moderate to heavy work in tropical farming. Industrial health. 2007;45(1)107-117. [Crossref]

14. O'Grady NP, Barie PS, Bartlett JG, et al. Practice guidelines for evaluating new fever in critically ill adult patients. Clinical infectious diseases. 1998;26(5)1042-1059.

[Crossref]

15. Motamedzade M, Azari MR. Heat stress evaluation using environmental and biological monitoring. Pakistan Journal of Biological Sciences. 2006;9(3)457-459.

[Crossref]

16. Brugniaux JV, Niva A, Pulkkinen I, Laukkanen RM, Richalet J-P, Pichon AP. Polar Activity Watch 200- a new device to accurately assess energy expenditure. British journal of sports medicine. 2010;44(4)245-249.

[Crossref]

17. Nag $P$, Sebastian N, Malvankar M. Effective heat load on agricultural workers during summer season. Indian J Med Res. 1980 Sep;72;408-15. [Crossref]

18. Alpérovitch $A$, Lacombe J-M, Hanon $O$, et al. Relationship between blood pressure and outdoor temperature in a large sample of elderly individuals- the Three-City study. Archives of internal medicine. $2009 ; 169(1) 75$.

[Crossref]
19. Epstein Y, Moran DS. Thermal comfort and the heat stress indices. Industrial Health. 2006;44(3)388-398.

[Crossref]

20. Kristal-Boneh E, Harari G, Green MS, Ribak J. Seasonal changes in ambulatory blood pressure in employees under different indoor temperatures. Occupational and environmental Medicine. 1995;52(11)715-721.

[Crossref]

21. Hata T, Ogihara T, Maruyama A, et al. The seasonal variation of blood pressure in patients with essential hypertension. Clinical and Experimental Hypertension. 1982;4(3)341-354. [Crossref]

22. Kim Y-M, Kim S, Cheong H-K, Ahn B, Choi K. Effects of Heat Wave on Body Temperature and Blood Pressure in the Poor and Elderly. Environmental health and toxicology. 2012;27. [Crossref]

23. Galloway SD, Maughan RJ. The effects of substrate and fluid provision on thermoregulatory and metabolic responses to prolonged exercise in a hot environment. Journal of Sports Sciences. 2000;18(5)339-351. [Crossref]

24. Inbar O, Morris $\mathrm{N}$, Epstein $\mathrm{Y}$, Gass $\mathrm{G}$. Comparison of thermoregulatory responses to exercise in dry heat among prepubertal boys, young adults and older males. Experimental physiology. 2004;89(6)691-700.

[Crossref] 